\title{
ANNALS
}

OF

\section{The Entomological Society of America}

\section{ON THE SOUTH AMERICAN SPECIES OF THE DIPTEROUS GENUS CHIROMYZA WIED.}

\author{
By Professor M. Bezzi, \\ Turin, Italy.
}

In the recently published Revision of the Chiromyzini by Mr. G. H. Hardy* Australian forms only have been dealt with. In the present paper the writer will take into consideration South American forms only.

Agreeing with Verrall (Brit. Flies V, p. 44) the Chiromyzini are accepted here as a tribe of. the family Stratiomyiidæ, chiefly on account of the form and position of the præfurca; but they have many important characters in common with the Rhagionida.

The main character of the tribe is that of the atrophied mouth parts, which must be in correlation with some peculiar habits of the adult flies. In addition may be recorded the sunken face and the greatly developed and apparently bisected front coxæ. The third antennal joint is more or less distinctly annulated; the last abdominal segments of the female are ovipositor-like; the tibiæ are not spurred. The wings have the ambient vein complete, even if sometimes very thin; a short præfurca; only 4 posterior cells, all open; the anal cell closed and stalked, but long.

Because of the normally developed mouth parts the genus Allognosta must be placed in the Beridini.

A peculiar feature of the Chiromyzini is the great variability in venation of the wings. Mr. Hardy points out that in $\mathrm{XXX}$

*Proceedings of the Linn. Soc. of N. S. W. XLV, 1920, p. 532-542, pl. XXIX- 
Australian forms even the upper branch of the cubital fork may be variable, being present in some specimens of one species and wanting in others. I have never found this to be the case with South American forms, which all have an unforked cubital vein, except in Hylorus. I have observed the following anomalies:

(a) The hind cross-vein may be more or less obliterated, in part or as a whole, the discoidal cell being thus partly or entirely open.

(b) The third vein issuing from the discoidal cell may be quite wanting or represented by a short stump.

(c) The ambient vein may be sometimes rather indistinct, chiefly in female specimens.

It is evident that this variation by reduction refers chiefly if not exclusively to the veins of the hind half of the wings. It may be interpreted as a condition of the true Stratiomyiid flies, in which the veins of the fore half only are thickened and crowded together near the costa, and as a tendency toward degeneration of wing, a fact which has reached its climax in the Australian genus Boreoides with subapterous females.

The South American genera of the tribe may be distinguished as follows:

1. (2) Third longitudinal vein forked; eyes bare and united in the male; third antennal joint with numerous annulations...............Hylorus Phil.

2. (1) Third longitudinal vein simple; third antennal joint with less than 8 annulations.

3. (6) Eyes of male united, quite bare or with few and scattered hairs; third antennal joint more or less distinctly annulated or even simple.

4. (5) First antennal joint much longer than the second, being as long as the third..............................................

5. (4) First antennal joint as long as the second and much shorter than the third; metapleura with short hairs; wings with microscopical pubescence and with the first longitudinal vein clothed with short hairs...... Chiromyza Wied.

6. (3) Eyes of male broadly separated, and clothed with abundant and short hairfir hird antennal ioint with deen annulation and much longer than the 


\section{Chiromyza Wiedemann.}

The genus Xenomorpha Macquart, with the type leptiformis Macq. from Rio Janeiro, is evidently the same; likewise the genus Nonacris Walker.* with the type transequa Walk. from South America; and even the genus Lagarus Philippi with the type paulseni Phil. from Chile, and Lagarinus Enderlein with the type paradoxus End. from Chile, as pointed out by Mr. Hardy.

It may be noted that in the original figure of the type species by Wiedemann the second longitudinal vein of the wings was omitted, perhaps accidentally. This vein is well shown in the figure of Xenomorpha by Macquart.

The South American forms before me can be distinguished as follows:

1. (8) Anal cell long, its terminal stalk being much shorter than the preceding part of the postical vein; halteres and coxæ of a pale yellowish color.

2. (7) The fourth longitudinal vein is forked before the hind crossvein, which is always complete; the second posterior cell is therefore sessile and rather obtuse at base; the third vein issuing from the discoidal cell frequently present in the shape of a short stump; scutellum never greenish.

3. (4) Back of thorax with four longitudinal dark stripes; pleuræ with several

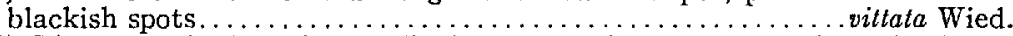

4. (3) Thorax with three longitudinal stripes only, or not evenly striped.

5. (6) The 3 dark stripes on thorax are broad and partly confluent, the back appearing thus in great part infuscated...............fuscana, Wied

6. (5) The above named stripes less developed and of ten obliterated, the back appearing for the most part reddish yellow............... ochracea Wied.

7. (2) The fourth vein forks beyond the hind cross-vein, which is often obliterated in its upper portion, or quite wanting; the second posterior cell is therefore acute at base and mostly provided with a short stalk; the rudiment of the third branch of media is never present; sides of thorax and of scutellum

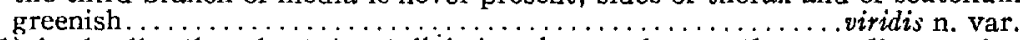

8. (1) Anal cell rather short, its stalk being about as long as the preceding portion of the postical vein; the whole antennæ, the halteres and the coxæ quite

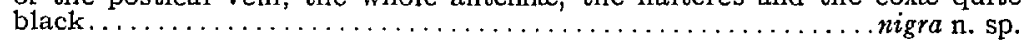

\section{Chiromyza vittata Wied. (leptiformis Macq.)}

As shown in the original figures by Wiedemann and by Macquart, the main character of the present form is that of the divided middle dark stripe of the back of mesonotum, which has therefore 4 longitudinal stripes. I have in my collection 3 female specimens from $\mathrm{S}$. Sebastiao, seashore of the State of S. Paulo, Brazil, collected by the Count $A$. A. Barbiellini. They agree in having the discoidal cell broad and obtuse outwardly, the second posterior cell with broad sessile base, the anal cell with short terminal stalk. One specimen only shows the short basal rudiment of $M 3$. The scutellum of the female has a shining black depression on each side at base; the same depression in the male is reddish or only a little darkened.

*It must be noted that in the original description for "Fourth posterior areolet closed before the border", the anal cell is meant. 


\section{Chiromyza vittata fuscana Wied.}

Numerous specimens of both sexes, some in copula, from Puerta Bertoni, Alto Parania, Paraguay, June, 1919, collected by Mr. C. Schrottky. One male specimen from S. Sebastiao, Brazil, by A. A. Barbiellini.

These specimens agree in having the middle dark stripe of thorax undivided, and usually prolonged behind to the scutellum; the back of mesonotum is broadly infuscated; the dark spots of the pleuræ are less developed; the scutellar depressions as in the preceding.

The venation is as in vittata; the rudiment of $M 3$ is present in 11 specimens of 12 . There are frequently abnormal cross-veins in the base of the second posterior cell, forming 1-4 small supernumerary cells; they are present in all the female specimens, but are not symmetrically placed, being often present on one wing only.

\section{Chiromyza vittata ochracea Wied.}

\section{(? transequa Walk.)}

This is the palest of all the forms, with unspotted pleuræ and bright orange abdomen.

One male specimen from S. Paulo, Brazil, March, 1906 (R. von Ihering). Agreeing in venation with the preceding forms; there is no rudiment of M 3.

\section{Chiromyza vittata viridis $n$. var.}

Two males from S. Paulo, Brazil (A. A. Barbiellini). They seem to agree with ochracea Schiner in being more slender than the preceding forms.

Male, length of body, $8-9 \mathrm{~mm}$; of wing, $8-9 \mathrm{~mm}$.

Eyes closely approximated, but a very small stripe of the frons is visible between them. Third antennal joint twice as long as the two first joints together, black, pilose, distinctly annulated.

Thorax reddish on the back, with three less marked dark longitudinal stripes; pleuræ pale yellowish, unspotted; the sides of the back posteriorly and the border of the scutellum are distinctly greenish. Halteres pale yellow as in all the preceding forms. Abdomen entirely orange, more pale on the venter. Coxæ and legs entirely pale yellowish, with last tarsal joint blackened; trochanters greenish. Wings yellowish, hyaline. One of the two specimens has the discoidal cell complete; in the other only a stump of the hind cross vein is present inferiorly, the cell being broadly open. Both specimens have the second posterior cell acute at base and there provided with a short stalk, which forms a common basal stem for $\mathrm{M}_{1}$ and $\mathrm{M}_{2}$; the discoidal cell is acute outwardly; there is no rudiment of $\mathrm{M}_{3}$; the terminal stalk of the anal cell is short as usual. The present species shows that the condition of Lagarinus is a casual one; but Enderlein's species has the third antennal joint not annulated. 
5. Chiromyza nigra n. spec.

Type $\sigma^{x}$, a single specimen in the writer's collection from Ecuador, received many years ago from Dr. J. Escher-Kundig, Zurich, Switzerland.

This may be a melanic mountain form, but it is here described as specifically distinct, chiefly on account of the peculiar shape of the anal cell, which recalls the condition of this same cell in the Beridina.

$\sigma^{7}$ Length of body $11 \mathrm{~mm}$., of wing $10 \mathrm{~mm}$.

Head entirely black, but the occiput and the face densely covered with a dark gray dust. Ocellar tubercle deep black. Eyes bare, intimately united, no distinct line being visible between them. Antennæ entirely black; the 2 basal joints are of about equal length; the third joint is only a little longer than the two first joints together; it is pilose, but I cannot perceive trace of its annulation because of its bad preservation. Mouth parts rudimentary as usual.

Thorax blackish-brown on the back, more reddish on the sides, with a short darkish pubescence; pleuræ dark brownish, more pale on the sternopleura; hairs of meso- and metopleura very short. Scutellum blackish, with more pale border; lateral depressions black. Halteres with yellowish stalk, but with a black knob.

Abdomen dull black, with shining black genitalia, which have the upper lamella deeply emarginate and yellowish at end. Venter yellowish grey. Coxæ shining black, with the sutures reddish; femora yellowish, with the apical part blackish-brown; tibiæ and tarsi almost entirely blackened, only the base of tibiæ and of prætarsi being more pale; claws black, with reddish base; the 4 posterior tibix are thickened and a little curved as usual.

Wings greyish hyaline, with a faint yellowish tint on costal cell. Discoidal cell open, only the lower part of the hind cross vein being present; no rudiment of $M_{3}$. Second posterior cell acute at base. The two branches of $\mathrm{M}$ and the distal portion of upper branch of $\mathrm{Cu}$ are very faint, almost spurious, perhaps due to immaturity of specimen. The stalk of the anal cell is much longer than in any of the preceding forms of vittata, being about as long as the preceding part of the postical vein; surface of wing is microscopically pubescent as usual.

\section{Barbiellinia new genus.}

Closely allied with Chiromyza, but at once distinguished by the long haired and broadly separated eyes of the male; moreover the hairs of the body, legs and wings are much more developed than in the allied forms. According to Mr. Hardy, Australian species of Chiromyza have either contiguous or separated eyes in the males; but the present case is the first known among Brazilian forms, and is here assumed as being of generic value on account of the unusual hairiness of the eyes.

Head rounded, rather small size, more narrow than the thorax. Occiput triangularly excavated above, with no prominent borders. The three ocelli are of rather large size, placed in an equilateral triangle on 
an inconspicuous plate. Eyes rounded, with equal areolets, clothed with numerous, but not dense, long hairs. Frons with parallel sides, only a little constricted towards its middle, not at all prominent in profile, about a half of the breadth of one eye. Antennæ inserted below; the second joint being a little longer than the first; third joint as long as the two first joints together, divided into three parts by two complete and deep annulations; it is entirely clothed with rather long hairs, like the basal joints. Face receding, sunken in the middle as in the Rhagionida. Mouth parts rudimentary; proboscis atrophied, palpi very small. Thorax greatly developed, almost puffed up and convex above; metapleura with long, erect hairs. Scutellum elongated, rounded behind, flat above, with well developed basal depressions on the sides, destitute of longer hairs at hind border. Halteres large, with oval knob; squamulæ rudimentary. Abdomen flattened, composed of 7 segments, the last of which is only one-half as long as the preceding one; genitalia small, but open. Legs long, intermediate pair shortest. Front coxæ greatly developed and apparently bisected, the plate above them being very large; middle and hind tibiæe distinctly curved and thickened; claws and pulvilli proportionately small. Pubescence of legs and hairs of coxæ longer than in Chiromyza. Wings distinctly pubescent on the whole surface; first and third longitudinal veins clothed with long hairs above. Præfurca short, originating over the base of the discoidal cell. Second longitudinal vein short; third vein single, ending before the tip of the wing; costa thickened to a short space beyond the tip of third vein, but prolonged as a thin ambient vein along the whole hind border of the wing. Discoidal cell complete, about as long as broad, obtuse at its distal end; second posterior cell sessile at base, the $M$ forking before the hind cross vein; the rudiment of $\mathrm{M}_{3}$ is wanting. Stalk of the anal cell short, much shorter than the preceding part of the postical vein. Alula rudimentary. Hind border of the wing with rather long ciliation.

Named in honor of the Count A. A. Barbiellini, who during the long years of his residence in S. Paulo has greatly contributed to the progress of entomological studies in Brazil, by the publication of the Journal "O Entomologista Brasileiro" 19081910 , and now by the general Review "Chacaras e Quintaes." The writer is indebted to him for large collections of Brazilian Diptera, the exposition of which will appear in the future.

Type: the following new species.

Barbiellinia hirta n. sp.

Type $\sigma^{7}$ a single specimen in the writer's collection from Terme do Lindoya (1000 m.), Serra Negra, Eita do do S. Paulo, Brazil, March, 1918. (A. A. Barbiellini).

$\sigma^{7}$ Length of body $8 \mathrm{~mm}$; of wing $8 \mathrm{~mm}$. 
Head entirely yellowish, the occiput whitish, dusted; ocellar plate black; occipital border with a narrow white line and with erect black hairs. Frons with a narrow, less distinct, dark transverse band on the middle, whole length clothed with erect black hairs. Antennæ entirely yellowish, black haired. Hairs of the eyes black. Face with black hairs on the sides; palpi reddish. Thorax on the back yellowish-brown, with rather long dark pubescence; the middle of the dark longitudinal stripes is abbreviated behind, divided along the middle by a pale line, but the lateral ones are not distinct. Pleuræ pale yellowish, unspotted, with rather long hairs on the mesopleura, and with longer ones on the metapleura. Scutellum like the thorax, with short dark pubescence. Halteres pale yellowish, dirty on the knob. Mesonotum pale yellowish. Abdomen yellowish above, rather shining, with blackish pubescence; all the segments are narrowly black on the sides; venter pale yellowish; genitalia quite reddish, even on the upper lamella and lateral appendages. Coxa and legs entirely pale yellowish, the last tarsal segments only being blackened; coxæ clothed with rather long black hairs, even the black pubescence of the remainder of the legs being longer than usual. All the femora are equally thin; front tibix thin, much more slender than the others; claws proportionally short; the three pulvilli dirty yellowish. Wings grayish hyaline, with dark yellowish veins, the basal portion of the fourth longitudinal vein being whitish.

ADDITIONAL NOTE.

Having received a paratype of Boreoides subulatus, through the courtesy of Mr. G. H. Hardy, and comparing it with the types of Boreoides tasmaniensis I have found:

(a) That the differences in the annulation of the third antennal joint and in the position of the hind coxæ are not consistent, these organs being not differently shaped or located in both the species.

(b) On the contrary the differences in the form of the scutellum, in the length of the wing-rudiments and in the coloration of thorax, are of great importance.

I find, moreover, that the legs of tasmaniensis are thinner and more slender than in subulatus, which is chiefly evident in the tarsi, which are not at all incrassated in the former. Even the color of the legs is lighter in tasmaniensis, the tibiæ and tarsi being entirely yellowish, while in subulatus they are in greatest part black. The two species are without doubt distinct; and Mr. Hardy informs me that even in Australia there are several different species of Boreoides not yet described.

\section{ADDITIONAL NOTE (2).}

In the meantime a paper by Dr. Günther Enderlein, Berlin, has appeared (Ueber die phyletisch älteren Stratiomyiidensubfamilien, in Mitteil. Zoolog. Mus. Berlin, X, 1921, pp. 153-214), in which a new classification of the Chiromyzini is proposed, with the descriptions of many new genera and species. 
The South American species with contiguous eyes of the male are subdivided between the genera Xenomorpha Macquart, Mesomyza Enderlein and Nonacris Walker; while those with the separated and hairy eyes of the male are united in the genus Chiromyza Wiedemann. But this proceeding is evidently contrary to Wiedemann's statement, which says in the original diagnosis of the genus: "** * oculi maribus contigui: * * * Augen beim Männchen zusammenstossend * * *" I am therefore of the opinion that the nomenclature used by me is more correct. The type species vittata Wiedemann was described only from the female sex, and thus there are no male types of it; Enderlein moreover, has not seen the female type. The genus Inopus is placed in synonymy with Xenomorpha; the genera Lagarus and Lagarinus are not mentioned at all. 